\title{
BREASTFEEDING DURATION AS A PREDICTOR OF CHILDHOOD LIFESTYLE HABITS, OVERWEIGHT AND OBESITY IN SECOND- AND THIRD-GRADE SCHOOLCHILDREN IN CROATIA
}

\author{
Maja Lang Morović ${ }^{1}$ and Sanja Musić Milanovićê,3 \\ ${ }^{1}$ Croatian Institute of Public Health, Division of Health Promotion, Zagreb, Croatia; \\ ${ }^{2}$ Department of Medical Statistics, Epidemiology and Medical Informatics, Andrija Štampar \\ School of Public Health, Zagreb, Croatia; ${ }^{3}$ School of Medicine, University of Zagreb, Zagreb, Croatia
}

\begin{abstract}
SUMMARY - Breastfeeding is related to better overall health in adult life and is one of the commonly described protective factors for childhood obesity. The purpose of this study was to describe the relationship between breastfeeding duration, childhood lifestyle habits, overweight and obesity in a cohort of Croatian second- and third-grade schoolchildren. Randomly selected second- and thirdgrade children aged 6-11 years $(\mathrm{N}=5662)$ were measured for weight and height in order to calculate nutritional status for each child. Also, a self-reported questionnaire was filled in by the parents to gather information on the child including breastfeeding duration, dietary and physical activity habits, and health risk behaviors. Regression analyses were performed to explore associations between breastfeeding duration and the odds of having dietary, physical activity or overall health risk behaviors, or of being overweight or obese. Significant associations were found showing that children who were breastfed for less than 6 months had higher odds for being overweight $\left(\mathrm{OR}_{\mathrm{adj}}=1.24 ; 95 \% \mathrm{CI} 1.04-\right.$ 1.47) or obese $\left(\mathrm{OR}_{\mathrm{adj}}=1.25 ; 95 \% \mathrm{CI} 1.02-1.53\right)$. After adjusting for confounders, breastfeeding for less than 6 months was not found to be predictive of dietary, physical activity or overall health risk behaviors. In conclusion, breastfeeding for longer than 6 months is a protective factor for overweight and obesity in 6-to 11-year-old children in Croatia, but not for healthy lifestyle development.
\end{abstract}

Key words: Child; Breastfeeding; Protective factors; Health risk behaviors; Obesity; Nutritional status; Croatia; Healthy lifestyle

\section{Introduction}

With continuing progression of science in the area, public health professionals are gaining more insight into the relationships between health risk factors and mechanisms of development and prevention of noncommunicable diseases. Consequently, it is becoming

Correspondence to: Asst. Prof. Sanja Musić Milanovic, MD, PhD, Andrija Štampar School of Public Health, Department of Medical Statistics, Epidemiology and Medical Informatics, School of Medicine, University of Zagreb, Rockefellerova 4, HR-10000 Zagreb, Croatia

E-mail: sanja.music@hzjz.hr

Received May 30, 2019, accepted July 9, 2019 clear that programming of adult disease outcomes emerges early in life and that, in particular, the first 1000 days play a predominant role in lifelong health ${ }^{1}$.

One of the most often-described protective factors for health is breastfeeding. Long-term, physical and psychological benefits of breastfeeding for both infant and mother are numerous and widely described ${ }^{2}$. The World Health Organization (WHO) recommends initiation of breastfeeding within the first hour after birth and continuation of exclusive breastfeeding until at least six months-of-age when complementary food should be gradually introduced. Nevertheless, it is advised to continue breastfeeding until the child is at least two years old ${ }^{3}$. 
Breast milk is the newborns' first and best food, it is free, and is often referred to as the individualized medicine'4. However, the prevalence of breastfeeding remains rather low. In the United States in 2015, the mean prevalence of women exclusively breastfeeding their children by the age of three months was $46.9 \%$, and by 6 months $24.9 \%$. The prevalence of breastfeeding in Europe is somewhat higher. In 2005, 59.2\% of infants were breastfed at the age of 3 months and $47.3 \%$ of infants were breastfed at the age of 6 months ${ }^{6,7}$. Among systematically examined infants in Croatia in 2016, 78.8\% of 0-2 month-old infants were exclusively breastfed, $10.9 \%$ were fed with breast milk and its substitutes, $10.3 \%$ were formula-fed, whereas for $25.4 \%$ data on infant feeding type were lacking. After the first three months of life, the proportion of infants exclusively breastfed decreased to $71.7 \%$, and the proportion of infants exclusively breastfed after the sixth month of age decreased to $10.7 \%$.

Besides its protective function in fighting infections in infancy, breastfeeding is related to better overall health in adult life, and is an unsubstitutable mechanism of prevention of non-communicable diseases ${ }^{9}$. Breastfeeding has also been found to be a protective factor for obesity ${ }^{10}$. Obesity represents a risk factor for today's leading non-communicable diseases including cardiovascular diseases, type 2 diabetes, chronic obstructive pulmonary disease, some types of cancers and mental diseases ${ }^{11}$. Obese children often become obese adults, making the health risk even greater ${ }^{12}$. Over the last three decades, there has been a rise in childhood obesity worldwide, regardless of the level of development of the country ${ }^{13}$. The prevalence of childhood obesity is at its historically highest level, and it presents one of the major public health concerns and priorities worldwide, being called a time bomb for future demands on healthcare services ${ }^{14}$. The etiology of obesity in childhood is complex. It is a result of interplay between genetic, prenatal and environmental factors, early life determinants, and individual lifestyle habits ${ }^{15}$.

Being the first food, breastfeeding practices in infancy are related to food choices and dietary habits later in life ${ }^{16}$. Also, mothers who breastfeed their children for a recommended period of time are setting building blocks of healthy lifestyle habits for their offspring. Along that note, the purpose of this study was to examine the protective power of breastfeeding lasting for six months or longer on childhood lifestyle habits observed as food and physical activity risk behaviors, overweight and obesity in a cohort of Croatian second- and third-grade schoolchildren.

\section{Subjects and Methods}

This study was conducted as part of the WHO Europe Childhood Obesity Surveillance Initiative (COSI), for Croatian purposes designed to trace obesity prevalence in 8.0-8.9 year-old-children ${ }^{17}$. COSI was established as a coordinated surveillance system among children in elementary school in order to gather Europewide, comparable data on children's anthropometric measurements including body height, weight, and waist and hip circumference to record and monitor trends in nutritional status among children aged 6.0-9.9 years. The general design of the COSI research has been described in detail by the WHO team ${ }^{18}$. In Croatia, COSI was conducted in accordance with the COSI Protocol, initiated in the 2015/2016 academic year, during the fourth European round of study, and administered by the Croatian Institute of Public Health (CIPH) with support of the Ministry of Health $(\mathrm{MoH})$, Ministry of Science, Education and Sports (MSES) and World Health Organization Regional Office for Europe.

Sampling methods involved randomly selecting a nationally representative sample of second-grade classes. For every randomly selected second-grade class, a matching third-grade class from the same school was selected. Overall, 182 second-grade classes and 182 third-grade classes from 164 elementary schools were selected. All of the selected schools agreed to participate in the study. The overall response rate was $79.2 \%$ and the final sample included 5662 children aged 6 to 11 years (mean=8.6 years, $\mathrm{SD}=0.6$ ).

The information collecting conducted from October to December 2015 involved taking anthropometric measurements of children in the selected classes and was carried out in school facilities, mostly in gym halls or classrooms, during school-hours. Weight to the nearest $0.1 \mathrm{~kg}$ was measured using an electronic weight scale (SECA 877, Hamburg, Germany), while children were dressed in light gym clothing. Standing height was measured to the nearest $0.1 \mathrm{~cm}$ using stadiometer (SECA 217, Hamburg, Germany). For accuracy, the height was measured twice and the mean value of the two measurements was used on analysis. Body mass index (BMI) for age was calculated for each child as weight in kilograms divided by height in 
Table 1. Characteristics of study sample $(N=5662)$

\begin{tabular}{|c|c|c|c|}
\hline \multicolumn{2}{|l|}{ Variable } & \multicolumn{2}{|l|}{ Variable } \\
\hline Age (years), mean (SD) & $8.6(0.6)$ & \multirow{3}{*}{$\begin{array}{l}\text { Risk behaviors, n (\%): } \\
\text { Food risk } \\
\text { Low } \\
\text { Medium } \\
\text { High }\end{array}$} & \multirow{3}{*}{$\begin{array}{l}2471(47.6) \\
2430(46.8) \\
291(5.6)\end{array}$} \\
\hline Birth weight $(\mathrm{g})$, mean $(\mathrm{SD})$ & $3428.1(545.5)$ & & \\
\hline $\begin{array}{l}\text { Gender, n (\%): } \\
\text { Girls } \\
\text { Boys }\end{array}$ & $\begin{array}{l}2808(49.6) \\
2854(50.4)\end{array}$ & & \\
\hline \multirow{3}{*}{$\begin{array}{l}\text { Breastfeeding, } n(\%) \text { : } \\
\text { Never breastfed } \\
\text { 1-3 months of breastfeeding } \\
\text { 4-6 months of breastfeeding } \\
\text { 6-12 months of breastfeeding } \\
\text { 12-24 months of breastfeeding } \\
\text { 24+ months of breastfeeding } \\
\text { Missing data }\end{array}$} & \multirow{3}{*}{$\begin{array}{l}515(9.4) \\
1342(23.7) \\
1002(17.7) \\
1344(23.7) \\
887(15.7) \\
291(5.1) \\
281(4.7)\end{array}$} & $\begin{array}{l}\text { Physical activity risk }{ }^{\mathrm{b}, \mathrm{d}} \\
\text { Low } \\
\text { High }\end{array}$ & $\begin{array}{l}4369 \text { (88.9) } \\
543(11.1)\end{array}$ \\
\hline & & $\begin{array}{l}\text { Overall health risk }{ }^{\mathrm{c}, \mathrm{d}} \\
\text { Low } \\
\text { Medium } \\
\text { High }\end{array}$ & $\begin{array}{l}1880(40.5) \\
2569(55.3) \\
197(4.2)\end{array}$ \\
\hline & & \multirow{2}{*}{$\begin{array}{l}\text { Nutritional statuse }{ }^{\mathrm{e}} \mathrm{n}(\%) \text { : } \\
\text { Thinness } \\
\text { Normal weight } \\
\text { Overweight } \\
\text { Obese }\end{array}$} & \multirow[b]{2}{*}{$\begin{array}{l}55(1.0) \\
3567(63.0) \\
1209(21.3) \\
831(14.7) \\
\end{array}$} \\
\hline $\begin{array}{l}\text { Level of urbanization, } \mathrm{n}(\%) \text { : } \\
\text { Urban } \\
\text { Semi-urban } \\
\text { Rural } \\
\end{array}$ & \begin{tabular}{|l|}
$3245(57.3)$ \\
$1714(30.3)$ \\
$700(12.4)$ \\
\end{tabular} & & \\
\hline $\begin{array}{l}\text { Maternal educational level, n (\%): } \\
\text { Elementary school } \\
\text { High school } \\
\text { College degree or higher }\end{array}$ & $\begin{array}{l}339(7.2) \\
2823(60.3) \\
1520(32.5)\end{array}$ & & \\
\hline
\end{tabular}

$\mathrm{SD}=$ standard deviation; \% is stated as valid percentage (excluding missing data), unless otherwise stated;

${ }^{a}$ Food risk behavior score ranged 0-8 and was derived from the Family Form regarding the child's dietary habits. One point was assigned if the child was having breakfast $<7$ days/week, eating foods like potato chips (crisps), corn chips, popcorn or peanuts $>3$ days/week, eating foods like candy bars or chocolate $>3$ days/week, eating foods like biscuits, cakes, doughnuts or pies $>3$ days/week, and eating foods like pizza, French fries (chips), hamburgers, sausages or meat pies $>3$ days/week. Scores 0-2 presented low, 3-5 moderate and 6-8 high risk;

${ }^{b}$ Physical activity risk behavior score ranged $0-5$ and was derived from the Family Form regarding the child's physical activity habits. One point was assigned if the child was using inactive transportation going to and from the school, going to a sports or dancing club $<2 \mathrm{~h} /$ week, playing outside $<1 \mathrm{~h} /$ day, spending time in front of the screen $\geq 2 \mathrm{~h} /$ day, sleeping $<9 \mathrm{~h}$ /day. Scores $0-2$ presented low and 3-5 high risk;

'Health risk behavior score was created for each child by combining the 'food-risk behavior score' and the 'physical activity-risk behavior score' ranging from 0 (none of the health-risk behaviors present) to 13 points (all health-risk behaviors present). Scores $0-3$ presented low, 4-6 moderate and 7-13 high risk;

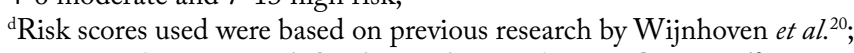

${ }^{\mathrm{e}}$ Nutritional status was defined according to the WHO criteria ${ }^{19}$.

centimeters in order to obtain the WHO nutritional categories for children ${ }^{19}$.

As part of the research, a self-reported questionnaire, the COSI Family Form, was completed by the parents to gather information on the child's physical activity and dietary habits, as well as family lifestyle data including short family medical history and socioeconomic status. More detailed description of the study sample is presented in Table 1.

\section{Study variables}

Data on the duration of breastfeeding were obtained from the COSI Family Forms. Parents or other caretakers were asked if the child had ever been breastfed and for how long, but not whether the child had been exclusively breastfed. Breastfeeding was observed as a dichotomous predictor of health risks in children. Children who had never been breastfed were excluded from further analysis, and the breastfed children were grouped into two categories of children breastfed for less than 6 months and children breastfed for 6 months or longer in accordance with the WHO recommendations ${ }^{3}$.

Health risk variables included child's lifestyle habits and child's weight status. Child's lifestyle habits were observed as three variables, i.e. 'food risk', 'physi- 
Table 2. Prevalence of individual food and physical activity risk behaviors $(N=5662)$

\begin{tabular}{|c|c|}
\hline \multicolumn{2}{|l|}{ Variable } \\
\hline \multicolumn{2}{|l|}{ Food risk, $\mathrm{n}(\%)$ : } \\
\hline Having breakfast $<7$ days/week & $1316(24.1)$ \\
\hline Eating fruit $<7$ days/week & $3629(66.2)$ \\
\hline $\begin{array}{l}\text { Eating vegetables (excluding potatoes) } \\
<7 \text { days/week }\end{array}$ & $4488(82.7)$ \\
\hline $\begin{array}{l}\text { Drinking soft drinks containing sugar } \\
>3 \text { days/week }\end{array}$ & $1639(30.4)$ \\
\hline $\begin{array}{l}\text { Eating foods like candy bars } \\
\text { or chocolate }>3 \text { days/week }\end{array}$ & $1718(31.4)$ \\
\hline $\begin{array}{l}\text { Eating foods like biscuits, cakes, } \\
\text { doughnuts or pies }>3 \text { days/week }\end{array}$ & $1470(26.8)$ \\
\hline $\begin{array}{l}\text { Eating foods like pizza, French fries } \\
\text { (chips), hamburgers, sausages or meat } \\
\text { pies }>3 \text { days/week }\end{array}$ & $276(5.0)$ \\
\hline $\begin{array}{l}\text { Eating foods like potato chips } \\
\text { (crisps), corn chips, popcorn or } \\
\text { peanuts }>3 \text { days/week }\end{array}$ & $655(12.0)$ \\
\hline \multicolumn{2}{|l|}{ Physical activity risk, $\mathrm{n}(\%)$ : } \\
\hline $\begin{array}{l}\text { Using inactive transportation going } \\
\text { to and from the school }\end{array}$ & $1691(30.7)$ \\
\hline $\begin{array}{l}\text { Going to a sports or dancing club } \\
<2 \mathrm{~h} / \text { week }\end{array}$ & $1930(35.2)$ \\
\hline Actively playing outside $<1 \mathrm{~h} /$ day & $458(5.6)$ \\
\hline Spending screen time $\geq 2 \mathrm{~h} /$ day & $2746(52.4)$ \\
\hline Sleep duration $<9 \mathrm{~h} /$ day & $332(6.1)$ \\
\hline
\end{tabular}

$\%$ is stated as valid percentage (excluding missing data)

cal activity risk' and 'health risk'. These risk variables were previously used by Wijnhoven et al. $^{20}$.

The food risk variable was created for each child as a score ranging from 0 (no risk) to 8 (maximum risk), based on the presence of eight food risk behaviors. Food risk behaviors were the following: having breakfast $<7$ days/week, eating fruit $<7$ days/week, eating vegetables (excluding potatoes) $<7$ days/week, drinking soft drinks containing sugar $>3$ days/week, eating foods like candy bars or chocolate $>3$ days/week, eating foods like biscuits, cakes, doughnuts or pies $>3$ days/week, eating foods like potato chips, corn chips, popcorn or peanuts $>3$ days/week and eating foods like pizza, French fries (chips), hamburgers, sausages or meat pies $>3$ days/week. Based on the scores, the categorical food risk variable was created. Scores $0-2$ were referred to as low food risk, 3-5 as moderate, and 6-8 as high food risk.

Physical activity risk score was also calculated as a sum of scores for each child. Each physical activity risk behavior was attributed one point. Physical activity risk was calculated based on the following behaviors: using inactive transportation going to and from the school, going to a sports or dancing club $<2 \mathrm{~h} /$ week, actively playing outside $<1 \mathrm{~h} /$ day, spending screen time $\geq 2 \mathrm{~h} /$ day, and sleep duration $<9 \mathrm{~h} /$ day. The score range was $0-5$ and was divided into two categories, i.e. $0-2$ considered as low and 3-5 as high physical activity risk.

The shares of children who had risk behaviors for each food risk variable and each physical activity risk variable used to calculate the score are shown in Table 2.

As a sum of food and physical activity risk scores, another variable of the health risk score was created. The health risk score ranged from 0 (no risk behaviors present) to 13 (all risk behaviors present) and was divided into the following three risk categories: no risk (0-3 points), moderate risk (4-7 points) and high risk (8-13 points).

Food, physical activity and health risk scores were attributed to children who had no missing values $(\mathrm{n}=4646)$.

Weight status variables included childhood 'overweight' and 'obesity' variables derived from child's BMI and based on the WHO criteria ${ }^{20}$.

Confounding variables in the study were age in months, sex, birth weight in grams, level of urbanization of the child's place of living (in accordance with the Croatian Bureau of Statistics definition of urban, semi-urban and rural settings ${ }^{21}$, and finally, socioeconomic characteristics of the family, described by the highest finished level of maternal formal education.

All investigated variables were acquired from the COSI Family Form that involved self-reporting by parents or other caretakers.

\section{Ethics}

The Ethics Committee of the Croatian Institute of Public Health approved the study in July 2015 (Class: 602-01/15-01/0242). The research was instigated following the ethical principles of autonomy, beneficence and nonmaleficence, and was conducted in accordance with the WHO COSI Protocol ${ }^{23}$. All procedures were in accordance with ethical standards of the responsible committee on human experimentation (institutional 
Table 3. Proportions of children breastfed for 6 months or longer and for less than 6 months according to gender, urbanization, maternal education, weight status, and food, physical activity and overall health risks

\begin{tabular}{|c|c|c|c|c|c|c|}
\hline & \multicolumn{2}{|c|}{$\begin{array}{l}\text { Breastfeeding }<6 \text { months } \\
(\mathrm{n}=1817)\end{array}$} & \multicolumn{2}{|c|}{$\begin{array}{l}\text { Breastfeeding } \geq 6 \text { months } \\
(\mathrm{n}=3049)\end{array}$} & \multirow[b]{2}{*}{$\chi^{2}$} & \multirow[b]{2}{*}{$\mathrm{df}$} \\
\hline & $\%$ & $\mathrm{n}$ & $\%$ & $\mathrm{n}$ & & \\
\hline \multicolumn{7}{|l|}{ Gender: } \\
\hline Girls & 37.1 & 893 & 62.9 & 1516 & \multirow{2}{*}{0.15} & \multirow{2}{*}{1} \\
\hline Boys & 37.6 & 924 & 62.4 & 1533 & & \\
\hline \multicolumn{7}{|l|}{ Urbanization level: } \\
\hline Urban & 34.4 & 954 & 65.6 & 1822 & \multirow{3}{*}{24.18} & \multirow{3}{*}{$2^{* *}$} \\
\hline Semi-urban & 41.2 & 612 & 58.8 & 873 & & \\
\hline Rural & 41.4 & 249 & 58.6 & 353 & & \\
\hline \multicolumn{7}{|l|}{ Maternal education: } \\
\hline Elementary school & 38.6 & 114 & 61.4 & 181 & \multirow{3}{*}{77.25} & \multirow{3}{*}{$2^{* *}$} \\
\hline High school & 42.9 & 1071 & 57.1 & 1426 & & \\
\hline College degree or higher & 28.6 & 396 & 71.4 & 988 & & \\
\hline \multicolumn{7}{|l|}{ Food risk ${ }^{\mathrm{a}}$ : } \\
\hline Low & 34.6 & 766 & 65.4 & 1448 & \multirow{3}{*}{12.92} & \multirow{3}{*}{$2^{*}$} \\
\hline Medium & 39.5 & 835 & 60.5 & 1281 & & \\
\hline High & 41.3 & 107 & 58.7 & 152 & & \\
\hline \multicolumn{7}{|l|}{ Physical activity risk ${ }^{\mathrm{b}}$ : } \\
\hline Low & 37.2 & 1443 & 62.8 & 2433 & \multirow{2}{*}{0.635} & \multirow{2}{*}{1} \\
\hline High & 39.1 & 180 & 60.9 & 280 & & \\
\hline \multicolumn{7}{|l|}{ Overall health risk ${ }^{c}$ : } \\
\hline Low & 34.6 & 585 & 65.4 & 1106 & \multirow{3}{*}{9.570} & \multirow{3}{*}{$2^{*}$} \\
\hline Medium & 39.4 & 883 & 60.6 & 1358 & & \\
\hline High & 38.2 & 68 & 61.8 & 110 & & \\
\hline \multicolumn{7}{|l|}{ Nutritional status ${ }^{\mathrm{d}}$ : } \\
\hline Underweight & 37.5 & 15 & 62.5 & 25 & \multirow{4}{*}{13.789} & \multirow{4}{*}{$3^{*}$} \\
\hline Physiological weight & 35.5 & 1095 & 64.5 & 1990 & & \\
\hline Overweight & 39.5 & 410 & 60.5 & 628 & & \\
\hline Obesity & 42.3 & 293 & 57.7 & 400 & & \\
\hline
\end{tabular}

$\mathrm{df}=$ degree of freedom; ${ }^{*} \mathrm{p}<0.01 ;{ }^{* *} \mathrm{p}<0.001$

and national) and with the Helsinki Declaration of 1975, as revised in 2008.

\section{Statistics}

All statistical analyses were performed using the SPSS Statistics 21.0 statistical package (IBM Corporation, Chicago, IL, USA). All analyses were performed on a weighted sample to account for nonresponse and noncoverage. Proportions were computed for categorical variables. The relationships between breastfeeding duration as a dichotomous variable and other variables were analyzed by $\chi^{2}$-test. Further, simple ordinal logistic regression analyses adjusted for child's age and sex were performed, and odds ratios (OR) and 95\% confidence intervals (CI) were obtained to explore associations between breastfeeding duration for more or less than 6 months and the odds of having overall health risk behaviors. The test of parallel lines was carried out to test the proportional odds assumption and the assumption was not rejected. For the as- 
sociation between food risk and breastfeeding duration, multinomial logistic regression was used because of non-proportional odds in the adjusted model. The association between breastfeeding duration and physical activity risk was tested using binary logistic regression. Multinomial logistic regression was also used to test the association between breastfeeding duration and nutritional status.

Finally, multivariable logistic regression analyses, adjusted for socio-demographic factors including age, sex, birth weight in grams, urbanization level, parental education, and risk factors including nutritional status, food and physical risk were performed and OR and 95\% CI were calculated to further analyze associations between breastfeeding duration for more or less than 6 months and the odds of having food, physical activity or overall health risk or being overweight or obese. Results were analyzed at $\alpha=0.05$.

\section{Results}

The initial sample included 5662 children who were present at the school on the day of measurements. The study subgroup included 4866 children who had been breastfed. The subgroup included in regression analyses consisted of 3383 subjects that had no missing data on any of the variables in the model. The proportions of children breastfed for less than 6 months and for 6 months or longer, according to study variables, are presented in Table 3. These results confirmed significant differences between the children breastfed for less than 6 months and for 6 months or longer in relation to urbanization level, maternal education level, food risk, overall health risk and nutritional status. The children living in urban areas tended to be less frequently breastfed for less than six months (34.4\%) than the others. The same held for the children whose mothers had a college degree or higher (28.6\%), children with low food risk (34.6\%) and low overall health risk (33.7\%), and children with normal weight (35.5\%).

Table 4 presents associations between breastfeeding for less than 6 months and study variables adjusted for age and sex. Significant associations were found showing that children who were breastfed for less than 6 months had higher odds for medium food risk $(\mathrm{OR}=1.24,95 \% \mathrm{CI} 1.07-1.43)$, higher odds for overall health risk $(\mathrm{OR}=1.19,95 \% \mathrm{CI} 1.04-1.37)$, and higher odds for being overweight (OR=1.21, 95\% CI 1.02-
Table 4. Simple and adjusted associations between childhood risk factors, overweight and obesity and breastfeeding duration $<6$ months in the group of children aged $6-11$ years in Croatia $(n=3383)$

\begin{tabular}{|c|c|c|}
\hline & $\mathrm{OR}(\mathrm{CI})$ & $\mathrm{OR}_{\mathrm{adj}}(\mathrm{CI})$ \\
\hline Food risk ${ }^{\mathrm{a}}$ : & & \\
\hline Medium & $1.24 *(1.07-1.43)$ & $1.16(1.00-1.34)$ \\
\hline High & $1.28(0.93-1.76)$ & $1.15(0.83-1.59)$ \\
\hline $\begin{array}{l}\text { Physical activity } \\
\text { high risk }\end{array}$ & $1.06(0.84-1.33)$ & $0.96(0.76-1.22)$ \\
\hline $\begin{array}{l}\text { Overall health } \\
\text { risk }^{c}\end{array}$ & $1.19^{*}(1.04-1.37)$ & $1.07(0.93-1.23)$ \\
\hline $\begin{array}{l}\text { Nutritional } \\
\text { status }^{\mathrm{d}}\end{array}$ & & \\
\hline Overweight & $1.21^{*}(1.02-1.43)$ & $1.24 *(1.04-1.47)$ \\
\hline Obesity & $1.26^{*}(1.04-1.54)$ & $1.25^{*}(1.02-1.53)$ \\
\hline
\end{tabular}

$\mathrm{OR}=$ odds ratio, $\mathrm{CI}=$ confidence interval;

${ }^{a}$ Food risk, an ordinal variable; odds ratios were calculated using multinomial logistic regression because of non-proportional odds in the adjusted model; low risk was set as a reference value;

'Physical activity risk, a dichotomous variable; odds ratios were calculated using binary logistic regression, low risk was set as a reference value;

'Health risk, an ordinal variable; odds ratios were calculated using ordinal regression; the proportional odds assumption was tested with the test of parallel lines and the assumption held both in the simple model $(\mathrm{p}=0.159)$ and adjusted model $(\mathrm{p}=0.240)$;

dNutritional status defined according to the WHO criteria ${ }^{20}$; odds ratios were calculated using multinomial logistic regression with normal weight set as a reference value.

1.43) or obese (OR=1.26, 95\% CI 1.04-1.54). We found no significant associations between breastfeeding shorter than 6 months and physical activity and high food risk behaviors in schoolchildren.

The associations were further analyzed in multivariate regressions, presented in Table 4, adjusted for age, gender, birth weight, urbanization level, maternal education level and other risk factors. The only association that remained significant was the one between breastfeeding duration and nutritional status. Even when adjusted for other factors, children who were breastfed for less than 6 months had higher odds for being overweight $\left(\mathrm{OR}_{\mathrm{adj}}=1.24,95 \% \mathrm{CI} 1.04-1.47\right)$ or obese $\left(\mathrm{OR}_{\mathrm{adj}}=1.25,95 \%\right.$ CI 1.02-1.53). These results indicated that breastfeeding duration could be considered as one of important predictors of nutritional status in school age children.

Simple models were adjusted for gender and age. The reference category for breastfeeding was 'duration 
for at least 6 months'. The sample included only those cases who had no missing data on all the variables used in the model. Children who were categorized as thinness according to the WHO criteria were excluded from analysis.

Models were adjusted for socio-demographic factors including gender, age, birth weight, parental education, urbanization level and risk factors including overweight, obesity, food and physical activity. Models were not adjusted for health risk as the sum of food and physical activity risks.

\section{Discussion}

We examined the association between breastfeeding duration and lifestyle habits, overweight and obesity in second- and third-grade schoolchildren in Croatia. Significant associations were found showing that children who were breastfed for less than 6 months had higher odds for being overweight and obese, even when adjusted for a variety of confounders such as child's age, sex and birth weight, urbanization level, maternal education level and child's other risk behaviors.

Without adjusting for other factors, children who were breastfed for 6 months and longer tended to have healthier dietary habits, i.e. eating breakfast every day, eating more fruit and vegetable and less foods high in sugars, salt and trans-fatty acids. Previous studies have confirmed that breastfeeding duration is associated with healthier food choices in children ${ }^{22}$. This association can be observed from early childhood and can be explained by the fact that children's food preferences appear to be shaped by exposure to foods and flavors from mother's diet in the pre- and postnatal period ${ }^{23}$ via amniotic fluid and breast milk ${ }^{24}$. For this reason, at the time of the introduction of solid foods, breastfed infants will have had more experience with tastes in comparison to their non-breastfed peers, which makes it easier for them to accept newly introduced flavors $^{25}$. Breastfeeding therefore provides a solid foundation for development of healthy eating habits in children.

When adjusted for other socio-demographic factors (maternal education and urbanization), physical activity risk behaviors, birth weight and current nutritional status, the association between breastfeeding and food risk was no longer significant. This indicated that breastfeeding duration could not be ob- served as a predictor of healthy dietary habits by itself. Children's dietary habits are greatly influenced by mother's and family's characteristics. These influences begin even before the introduction of solid foods $^{26}$ and mothers who choose to breastfeed are taking an important first step on the road to developing healthy dietary habits in the child. The next step is the weaning period during which complementary foods are introduced and lifelong eating habits may be established. It is therefore recommended to adhere to dietary guidelines during this period in order to develop healthy eating habits in children and prevent development of risk behaviors, and consequently, overweight and obesity in the child ${ }^{27,28}$.

The same pattern appears with the association of duration of breastfeeding under 6 months and overall health risk, which combines food and physical activity risk factors. These two risk behaviors combined are recognized to increase the risk of obesity and, consequently, development of a number of associated chronic conditions ${ }^{11}$. Although physical inactivity and screen-time as a sole risk factor was not found to be significantly associated with the duration of breastfeeding, breastfeeding for less than 6 months was a significant predictor of overall health risk when food and physical activity were combined. This result could be explained by the fact that food items contribute to the overall score more than physical activity items. Again, when adjusted for confounding factors, there was no significant association.

In both adjusted and unadjusted models we found a significant association showing that children who were breastfed for less than 6 months had higher odds for both overweight and obesity in school age than children who were breastfed for 6 months and longer. These results are in line with previous research indicating that breastfed children had lower odds of being overweight ${ }^{11}$, and once again confirm the protective power of breastfeeding in childhood overweight and obesity development. Although several studies dispute this relationship ${ }^{29}$, most of them show positive effects of breastfeeding on childhood overweight and obesity development. This positive effect of breastfeeding on child's weight has been hypothesized to be related to several biological mechanisms such as the role of breastfeeding in the regulation of infant appetite. Breastfed infants in comparison to formula-fed infants tend to have better control of their appetite, which en- 
ables them to be more proficient in hunger detection and limit food intake, a trait that persists to adulthood. Furthermore, breast milk contains leptin, which also may influence leptin level in childhood and later on in adolescence and adult life, but also helps regulate appetite and calorie metabolism in breastfed children ${ }^{30}$. Lastly, breastfeeding seems to be related to lower protein ingestion in comparison to formula feeding and this may lead to lipogenesis, development of fat cells and, without doubt, obesity ${ }^{31}$.

Our study had several limitations. First, there was a problem of recall bias since we used data on breastfeeding that were collected several years later. Second, considering the participation rate (79.2\%) and exclusion due to partial missing data, there was a certain selection bias. The sample that was selected for regression analysis was significantly different from the unselected one in the distribution of weight status, food risk, physical risk and overall health risk scores. The selected sample was more frequently overweight or obese but less frequently had high food, physical and overall health risk scores. Third, as noted, we only had data on the general duration of breastfeeding, and exclusivity of breastfeeding was not asked. The insight into exclusivity of breastfeeding would give us more detailed information on the benefits of breastfeeding for study outcomes. Fourth, since this was an observational study not designed to assess associations between breastfeeding and health risk behaviors or overweight/obesity, we had no information on the children's first foods and physical activity habits in early childhood, which would be beneficial in explaining the role of family and parenting styles in the child's habitual development. Another study, similar to ours, but with longitudinal character is therefore recommended. Fifth, we could only infer the implication of parenting styles and family functioning as these traits were not measured. Having these data could yield different results.

Despite these limitations, this was the first study to show the protective power of breastfeeding for longer than 6 months on childhood overweight and obesity status in Croatia. The results also indicated that breastfeeding duration could not be used as a predictor of healthy lifestyle habits. It is important to point out once again that we did not test breastfeeding as a predictor of health-related outcomes but only the duration of breastfeeding in case that the child was breast- fed at all. The findings from this study, drawn from a large, nationally representative random sample of children can be used in modeling and implementation of future public health and health promotion policies in promoting breastfeeding for longer than 6 months as a first step towards obesity prevention in children. These findings are also valuable in clinical practice and community nurse child visits. Pediatricians and community nurses should consider benefits of breastfeeding for longer than 6 months as the foundation of infant feeding and its role in child growth and development when counseling families who plan pregnancy, childbearing families and families with newborns and infants. It would also be helpful for providers to support and advise parents on the importance of complementary feeding, healthy eating guidelines and physical activity in early childhood, and suggest ways how parents can be active with their child. Establishing healthy eating and physical activity habits early in life could prove beneficial in halting the rise of childhood obesity worldwide.

\section{Acknowledgment}

The research was conducted with the financial and material support from the World Health Organization Regional Office for Europe and the Croatian Institute of Public Health.

\section{References}

1. Woo Baidal JA, Locks M, Cheng ER, Blake-Lamb TL, Perkins ME, Taveras EM. Risk factors for childhood obesity in the first 1,000 days. Am J Prev Med. 2015; 50(6):761-79. doi: 10.1016/j.amepre.2015.11.012.

2. Horta BL, Victora CG, World Health Organization. Longterm effects of breastfeeding: a systematic review. World Health Organization; 2013.

3. World Health Organization and UNICEF. Global strategy for infant and young child feeding. World Health Organization; 2003.

4. Anatolitou F. Human milk benefits and breastfeeding. J Pediatr Neonat Individual Med. 2012;1(1):11-8. doi: 10.7363/ 010113.

5. Centers for Disease Control and Prevention. National Immunization Survey (NIS). Breastfeeding among US Children Born 2002-2012. CDC National Immunization Surveys, 2015.

6. World Health Organization Regional Office for Europe. "\% of infants breastfed at age 3 months" European Health for All explorer. Web [Internet]. [cited 2018 Jul 18]. Available from: 
https://gateway.euro.who.int/en/indicators/hfa_615-7250-ofinfants-breastfed-at-age-3-months/.

7. World Health Organization Regional Office for Europe. "\% of infants breastfed at age 6 months" European Health for All explorer. Web [Internet]. [cited 2018 Jul 18]. Available from: https://gateway.euro.who.int/en/indicators/hfa_616-7260-ofinfants-breastfed-at-age-6-months/.

8. Croatian Institute of Public Health. Croatian Health Statistics Yearbook 2016. [Internet]. Croatian Institute of Public Health, 2017. [cited 2018 Jul 18]. Available from: https://www.hzjz.hr/ en/other-publications/croatian-health-statistics-yearbook2017/.

9. American Academy of Pediatrics. Policy statement: Breastfeeding and the use of human milk. Pediatrics. 2012;129(3): e827-e841.

10. Wang L, Collins C, Ratliff M, Xie B, Wang Y. Breastfeeding reduces childhood obesity risks. Child Obes. 2017;13(3):197204. doi: 10.1089/chi.2016.0210.

11. Gaining Health. The European Strategy for the Prevention and Control of Noncommunicable Diseases. [Internet]. World Health Organization; 2006. [cited 2018 Jul 18]. Available from: http://www.euro.who.int/_data/assets/pdf_file/0008/ 76526/E89306.pdf?ua=1.

12. Reilly JJ, Kelly J. Long-term impact of overweight and obesity in childhood and adolescence on morbidity and premature mortality in adulthood: systematic review. Int J Obes. 2011; 35(7):891. doi:10.1038/ijo.2010.222.

13. Black RE, Victora CG, Walker SP, Bhutta ZA, Christian P, De Onis M, Ezzati M, Grantham-McGregor S, Katz J, Martorell R, Uauy R, and the Maternal and Child Nutrition Study Group. Maternal and child undernutrition and overweight in low-income and middle-income countries. Lancet. 2013;382 (9890):427-51. doi: 10.1016/S0140-6736(13)60937-X.

14. Lobstein T, Jackson-Leach R, Moodie ML, Hall KD, Gortmaker SL, Swinburn BA, et al. Child and adolescent obesity: part of a bigger picture. Lancet. 2015;385(9986):2510-20. doi: 10.1016/S0140-6736(14)61746-3.

15. Bider-Canfield Z, Martinez MP, Wang X, Yu W, Bautista MP, Brookey J, et al. Maternal obesity, gestational diabetes, breastfeeding and childhood overweight at age 2 years. Pediatr Obes. 2017;12(2):171-8. doi:10.1111/ijpo.12125.

16. Robinson S, Marriott L, Poole J, Crozier S, Borland S, Lawrence $\mathrm{W}$, et al. Dietary patterns in infancy: the importance of maternal and family influences on feeding pracice. Br J Nutr. 2007;98(5):1029-37. doi: 10.1017/S0007114507750936.

17. Musić Milanović S, Lang Morović M, Markelić M. Childhood Obesity Surveillance Initiative Croatia 2015/2016 (CroCOSI), Zagreb: Croatian Institute of Public Health; 2018.

18. World Health Organization Regional Office for Europe. Childhood Obesity Surveillance Initiative (COSI) - Protocol October 2016. World Health Organization; 2017.
19. de Onis M, Onyango AW, Borghi E, Siyam A, Nishida C, Siekmann J. Development of WHO growth reference for school-aged children and adolescents. Bull World Health Organ. 2007;85(9):660-7. doi: 10.2471/blt.07.043497.

20. Wijnhoven TMA, van RaaijJM, Yngve A, Sjöberg A, Kunešová M, Duleva V, et al. WHO European Childhood Obesity Surveillance Initiative: health-risk behaviours on nutrition and physical activity in 6-9-year-old schoolchildren. Public Health Nutr.2015;18(17):3108-24.doi:10.1017/S1368980015001937.

21. Croatian Bureau of Statistics. The Model of the Differentiation of Urban, Rural and Semi-Urban Settlements in the Republic of Croatia. [Internet]. Zagreb, 2011. [cited 2017 Aug 1]. Available from: https://www.dzs.hr/Eng/Publication/metodologije/ metod_67.pdf.

22. Scott JA, Chih TY, Oddy WH. Food variety at 2 years of age is related to duration of breastfeeding. Nutrients. 2012;4 (10):1464-74. doi: 10.3390/nu4101464.

23. Mennella JA, Forestell CA, Morgan LK, Beauchamp GK. Early milk feeding influences taste acceptance and liking during infancy. Am J Clin Nutr. 2009;90:780S-788S. doi: 10.3945/ ajcn.2009.27462O.

24. Galef BG, Sherry D. Mother's milk: a medium for transmission of cues reflecting the flavor of mother's diet. J Comp Physiol Psychol. 1973;83:374-8. doi: 10.1037/h0034665.

25. Murray RD. Influences on the initial dietary pattern among children from birth to 24 months. Nutrition Today. 2017;52 (2):S25-S29. doi: 10.1159/000479246.

26. Pearce J, Langley-Evans SC. The types of food introduced during complementary feeding and risk of childhood obesity: a systematic review. Inl J Obes. 2013;37:477-85. doi: 10.1038/ ijo.2013.8.

27. World Health Organization. Obesity: preventing and managing the global epidemic. No. 894. World Health Organization; 2000.

28. Batista M, Žigić Antić L, Žaja O, Jakovina T, Begovac I. Predictors of eating disorder risk in anorexia nervosa adolescents. Acta Clin Croat. 2018;57(3):399-410. doi: 10.20471/acc.2018. 57.03.01.

29. Redsell SA, Edmonds B, Swift JA, Siriwardena AN, Weng S, Nathan D, et al. Systematic review of randomized controlled trials of interventions that aim to reduce the risk, either directly or indirectly, of overweight and obesity in infancy and early childhood. Matern Child Nutr. 2016;12:24-38. doi: 10.1111/mcn.12184.

30. Disantis KI, Collins BN, Fisher JO, Davey A. Do infants fed directly from the breast have improved appetite regulation and slower growth during early childhood compared with infants fed from a bottle? Int J Behav Nutr Phys Act. 2011;8:89. doi: 10.1186/1479-5868-8-89.

31. Papatesta E-M, Iacovidou N. Breastfeeding reduces the risk of obesity in childhood and adolescence. J Pediatr Neonat Individ Med. 2013;2:e20206. doi:10.7363/020206. 


\section{Sažetak \\ TRAJANJE DOJENJA KAO PREDIKTOR ŽIVOTNIH NAVIKA, PREKOMJERNE TJELESNE MASE I DEBLJINE U UČENIKA DRUGIH I TREĆIH RAZREDA OSNOVNIH ŠKOLA REPUBLIKE HRVATSKE}

\section{Lang Morovići i S. Musić Milanović}

Dojenje je povezano s cjeloživotnim zdravljem te predstavlja jedan od najčešće opisanih zaštitnih čimbenika za debljinu u djetinjstvu. Cilj ovoga rada je prikazati povezanost između duljine dojenja i životnih navika, prekomjerne tjelesne mase i debljine u kohorti djece drugih i trećih razreda osnovnih škola Republike Hrvatske. Učenicima slučajno odabranih drugih i trećih razreda osnovnih škola u dobi od 6-11 godina $(\mathrm{N}=5662)$ izmjerene su tjelesna visina i masa kako bi im se izračunao status uhranjenosti. Uz to, roditelji su ispunili upitnik u svrhu dobivanja podataka o djeci uključujući duljinu dojenja, prehrambene navike i navike tjelesne aktivnosti kao i ponašanja rizična za zdravlje. Provedena je regresijska analiza podataka kako bi se utvrdila povezanost između duljine dojenja i vjerojatnosti za rizična ponašanja u području prehrane, tjelesne aktivnosti i zdravlja uopće, kao i vjerojatnosti za prekomjernu tjelesnu masu i debljinu u djece. Djeca dojena kraće od 6 mjeseci imala su statistički značajno veću vjerojatnost za prekomjernu tjelesnu masu (prilagođeni omjer izgleda $\left(\mathrm{OI}_{\text {pril }}\right)=1,24 ; 95 \%$ interval pouzdanosti (IP) 1,04-1,47) i debljinu (OI ${ }_{\text {pril }}=1,25$; $95 \%$ IP 1,02-1,53). Nakon prilagodbe za čimbenike posredne povezanosti, dojenje kraće od 6 mjeseci nije bilo značajno povezano s proučavanim ponašanjima rizičnim za zdravlje. Duljina dojenja veća od 6 mjeseci predstavlja zaštitni čimbenik za prekomjernu tjelesnu masu i debljinu, ali ne i za zdrave navike u djece drugih i trećih razreda osnovnih škola Republike Hrvatske.

Ključne riječi: Dijete; Dojenje; Zaštitni čimbenici; Zdravstveno rizična ponašanja; Pretilost; Prehrambeni status; Hrvatska; Zdrav način života 